\title{
HUBUNGAN CARING PERAWAT DENGAN KEPUASAN PASIEN DI RSUD PURI HUSADA TEMBILAHAN
}

\author{
Apriza $^{1}$, Sri lestari ${ }^{2}$ \\ Dosen Program Studi Ners \\ Mahasiswa Program Studi Sarjana Keperawatan \\ Universitas Pahlawan Tuanku Tambusai \\ apriza@universitaspahlawan.ac.id
}

\begin{abstract}
Abstrak
Perawat dalam meningkatkan asuhan keperawatan untuk kebutuhan rasa kepuasan pasien hendaknya menerapkan penggunaan caring. Caring merupakan inti atau fokus dalam keperawatan sebagai bentuk praktik keperawatan profesional. Salah satu indikator mutu pelayanan keperawatan adalah kepuasan pasien dan caring perawat menjadi jaminan apakah layanan perawat tersebut bermutu atau tidak. Penelitian ini bertujuan untuk mengetahui hubungan caring perawat dengan kepuasan pasien di RSUD Puri Husada Tembilahan Tahun 2016. Penelitian ini dilaksanakan pada 04 s/d 25 April 2016, bersifat analitik dengan desain cross sectional dengan menggunakan data primer. Tehnik Sampel menggunakan total sampling dengan jumlah 127 responden yaitu pasien yang dirawat di RSUD Puri Husada Tembilahan. Analisa data dilakukan secara univariat dan bivariatdengan uji chi square. Instrumen penelitian menggunakan kuesioner. Hasil univariat menunjukkan bahwa $88(69 \%)$ responden mengatakan caring perawat baik dan $84(66,1 \%)$ responden mengatakan puas. Hasil analisa bivariat diketahui ada hubungan yang bermakna antara caring perawat dengan kepuasan pasien, dibuktikan dengan nilai $\mathrm{p}$ value $=0,020$ atau $\mathrm{p}<0,05$. Oleh karena itu diharapkan bagi tenaga kesehatan untuk dapat memasukkan peningkatan perilaku caring perawat dalam pemberian rasa kepuasan ke dalam perencanaan dan tujuan pelayanan keperawatan sekaligus dibuat kebijakan terkait caring dan rasa kepuasan pasien.
\end{abstract}

Kata kunci : Caring Perawat, Kepuasan Pasien

Kepustakaan : $28(2006-2016)$

$\triangle$ Corresponding author :

Address : Jl. Tuanku Tambusai No. 23 Bangkinang

Email : apriza@univeritaspahlawan.ac.id

Phone : 085211804568 


\section{PENDAHULUAN}

\section{A. Latar Belakang}

Era globalisasi yang sedang dan akan kita hadapi dibidang kesehatan, menimbulkan secercah harapan akan peluang meningkatnya pelayanan kesehatan. Terbukanya pasar bebas memberikan pengaruh yang penting dalam meningkatkan kompetisi disektor kesehatan. Persaingan antar rumah sakit memberikan pengaruh dalam manajemen rumah sakit baik milik pemerintah, swasta maupun investor asing dengan tujuan akhir adalah untuk meningkatkan pelayanan.

Rumah sakit merupakan salah satu jaringan pelayanan kesehatan yang penting, sarat dengan tugas, beban, masalah dan harapan yang digantungkan padanya. Rumah sakit yang baik adalah rumah sakit yang memiliki kemampuan dalam menghubungkan aspek-aspek kemanusiaan yang ada dengan programprogram pelayanan kesehatan (Wulan, 2011).

Undang-undang Republik Indonesia No 8 tahun 1999 tentang Perlindungan Konsumen menjelaskan salah satu tujuan dari perlindungan konsumen adalah meningkatkan kualitas kenyamanan, keamanan, dan keselamatan konsumen. Upaya yang dilakukan dalam meningkatkan pelindungan konsumen salah satunya dengan cara mengoptimalkan kinerja perawat dengan memberikan pelayanan yang profesional.

Keperawatan merupakan suatu bentuk pelayanan profesional yang mempunyai suatu paradigma atau model keperawatan yang meliputi empat komponen yaitu : manusia, kesehatan, lingkungan dan perawat itu sendiri. Perawat adalah suatu profesi yang mulia, karena memerlukan kesabaran dan ketenangan dalam melayani pasien yang sedang menderita sakit. Seorang perawat harus dapat melayani pasien dengan sepenuh hati. Sebagai seorang perawat harus dapat memahami masalah yang dihadapi oleh klien, selain itu seorang perawat dapat berpenampilan menarik. Untuk itu seorang perawat memerlukan kemampuan untuk memperhatikan orang lain, keterampilan intelektual, teknikal dan interpersonal yang tercermin dalam perilaku caring atau kasih sayang (Dwidiyanti,2007)
Perawat dalam meningkatkan asuhan keperawatan untuk kebutuhan rasa kepuasan pasien hendaknya menerapkan penggunaan caring. Caring merupakan inti atau fokus dalam keperawatan sebagai bentuk praktik keperawatan profesional. Caring sangatlah penting untuk keperawatan. Caring adalah fokus pemersatu untuk praktek keperawatan. Perilaku caring juga sangat penting untuk tumbuh kembang, memperbaiki dan meningkatkan kondisi atau cara hidup manusia (Blais, 2007).

Pasien merupakan orang yang kontak langsung dengan pelayanan keperawatan yang diberikan sekaligus menjadi pelanggan tetap yang diharapkan dapat menambah nilai usaha dan secara terus-menerus memberikan manfaat bagi rumah sakit dan loyalitas terhadap rumah sakit (Wijono, 2007). Meningkatkan loyalitas pasien terhadap rumah sakit perlu peningkatan mutu jasa pelayanan kesehatan yang merupakan suatu upaya untuk memberikan perlindungan kepada klien sebagai konsumen.

Salah satu indikator keberhasilan pelayanan kesehatan adalah kepuasan pasien. Kepuasan didefinisikan sebagai penilaian pasca konsumsi, bahwa suatuproduk yang dipilih dapat memenuhi atau melebihi harapan pasien, sehinggamempengaruhi proses pengambilan keputusan untuk pembelian ulang produkyang sama. Pengertian produk mencakup barang, jasa, atau campuran antara barang dan jasa (Depkes RI, 2008)

Indikator mutu untuk mengukur kepuasan pasien yang dirawat di rumah sakit antara lain jumlah dan jenis keluhan pasien dan keluarganya, surat keluhan pembaca di koran, surat kaleng, survei oleh lembaga survei independen untuk mengetahui tingkat kepuasan pengguna jasa pelayanan rumah sakit, menanyakan kepuasan pengguna pelayanan kesehatan melalui telepon dan sebagainya. Sedangkan indikator mutu pelayanan untuk mengukur tingkat efisiensi pelayanan rumah sakit antara lain unit cost rawat jalan rumah sakit, jumlah penderita yang mengalami decubitus, jumlah penderita yang jatuh dari tempat tidur, BOR (Bed Occupation Rate tingkat hunian rumah sakit), BTO (Bed Turn Over), TOI (Turn Over Interval), ALOS 
(Average Length Of Stay), Normal Tissue Removal Rate (Muninjaya, 2013)

Kepuasan pasien terhadap pelayanan dan asuhan keperawatan merupakan kepuasan akan mutu pelayanan yang diberikan tenaga perawat terhadap pasien selama dirawat di rumah sakit. Pelayanan dan asuhan keperawatan yang diberikan kepada klien merupakan bentuk pelayanan profesional yang bertujuan untuk membantu klien dalam pemulihan dan peningkatan kemampuan dirinya memalui tindakan pemenuhan kebutuhan klien secara komprehensif dan berkesinambungan sampai klien mampu untuk melakukan kegiatan rutinitasnya tanpa bantuan (Nurachmah, 2001).

Caring mengandung 3 hal yang tidak dapat dipisahkan yaitu perhatian, tanggung jawab, dan dilakukan dengan ikhlas (Sitorus, 2007). Caring juga merupakan sikap peduli, menghormati dan menghargai orang lain, artinya memberi perhatian dan mempelajari kesukaan - kesukaan seseorang dan bagaimana seseorang berfikir dan bertindak. Memberikan asuhan (caring) secara sederhana tidak hanya sebuah perasaan emosional atau tingkah laku sederhana, karena caring merupakan kepedulian untuk mencapai perawatan yang lebih baik, perilaku caring bertujuan dan berfungsi membangun struktur sosial, pandangan hidup dan nilai kultur setiap orang yg berbeda pada satu tempat (Dwidiyanti, 2007), maka kinerja perawat khususnya pada perilaku caring menjadi sangat penting dalam mempengaruhi kualitas pelayanan dan kepuasan pasien terutama di rumah sakit, dimana kualitas pelayanan menjadi penentu citra institusi pelayanan yang nantinya akan dapat meningkatkan kepuasan pasien dan mutu pelayanan (Potter, 2006)

Perilaku perawat yang berlandaskan pada caring dapat memberikan kepuasan pada pasien. Perilaku caring dalam praktik keperawatan sehari-hari belum banyak diterapkan oleh perawat, karena masih ada ditemuinya perawat yang judes, tidak sopan, pemarah, membentak, dan tidak tanggap pada pasien. Hal ini didukung oleh penelitian Rahayu (2001) dengan judul "faktor-faktor yang berhubungan dengan sikap caring yang di persepsikan oleh perawat pelaksana di ruang rawat inap RSUP Persahabatan" bahwa asuhan keperawatan dilihat dari sikap caring tampak adanya kondisi yang kurang positif, terlihat pada proporsi perawat yang caring $51,9 \%$ dan tidak caring $49,1 \%$.

Hasil penelitian yang sama dilaporkan oleh Muhasidah (2002) dengan judul "hubungan tehnik dan frekuensi supervise kepala ruangan dengan pelaksanaan caring untuk perawat pelaksana di RS Sumber Waras" bahwa distribusi perawat yang caring $49,7 \%$ dan yang tidak caring $50,3 \%$. Perawat yang berperilaku caring diharapkan dapat meningkatkan kesembuhan pasien.

Yusrizal (2001) dengan judul "faktor-faktor yang berhubungan dengan kepuasan pasien rawat inap di RSU Lubuk Linggau Sumatra Selatan" melaporkan bahwa kepuasan pasien rawat inap terhadap pelayanan keperawatan menunjukkan adanya kecendrungan yang kurang menggembirakan. Proporsi klien yang puas dan tidak puas tidak terlalu jauh berbeda yaitu $52,5 \%$ dan $47,5 \%$. Perawat dalam memberikan asuhan keperawatan lebih menekankan pada perilaku caring yang bersifat fisik atau kebiasaan manusia.

Caring dari rumah sakit ditunjang dengan adanya sumber daya manusia salah satunya perawat. Hasil wawancara bagian rekam medik yaitu BOR (Bed Occupation Rate) tahun 2014 yaitu 70,6\%, ALOS (Average Length Of Stay) 4 hari, TOI (Turn Over Interval) 2 hari dan tahun 2015 BOR (Bed Occupation Rate)yaitu 73\%, ALOS (Average Length Of Stay) 4 hari, TOI (Turn Over Interval) 1 hari, perawat di RSUD Puri Husada Tembilahan ada 180 orang pada tahun 2016 sehingga rasio antara perawat dan pasien ada 10 pasien dengan 1 perawat. Dengan banyaknya pasien tersebut interaksi perawat dengan pasien menjadi berkurang sehingga dapat menimbulkan kurangnya caring perawat dengan pasien.

Berdasarkan survey awal yang peneliti lakukan di RSUD Puri Husada, terdapat 7 responden mengungkapkan bahwa perawat jarang ke pasien, ke pasien hanya untuk rutinitas saja saat ada tindakan keperawatan dan 3 responden mengungkapkan bahwa perawat kurang lama berinteraksi dengan pasien dan kurang ramah terhadap pasien, 10 responden mengungkapkan bahwa perawat tidak menjelaskan tindakan yang diberikan kepada pasien sehingga pasien menyatakan ketidakpuasan terhadap pelayanan yang diberikan perawat selama dirawat di RSUD Puri Husada Tembilahan. 
Dari wawancara kepada perawat menyatakan bahwa keluhan pasien yang banyak sedangkan tenaga perawat yang kurang pada saat dinas sehingga pasien tersebut tidak terlayani dengan baik.Pada bidang keperawatan menyatakan keluhan pasien yang banyak terabaikan ada pada saat alat-alat untuk pelayanan tidak ada atau terjadi kerusakan sehingga pasien menyatakan ketidakpuasan terhadap pelayanan yang diberikan perawat.

Rekap komplain atau kotak saran dari Kepala Bagian Humas pada bulan Januari 2016 didapatkan data yang masuk sebanyak 16 diantaranya ada 9 komplain didapatkan bahwa pasien dan keluarganya mengeluhkan perawat tidak melayani dengan sabar, perawat tidak mendengarkan penuh perhatian keluhan pasien, perawat kurang lama berinteraksi dengan pasien hanya datang untuk rutinitas tindakan keperawatan saja dan perawat tidak menunjukkan empatinya kepada pasien,perawat judes, jarang berkomunikasi dengan pasien, kalau dipanggil tidak segera datang.

Pelayanan keperawatan prima harus diwujudkan untuk mendukung tersedianya pelayanan kesehatan yang berkualitas. Dalam deklarasi perawat Indonesia pada tahun 2012, Supriyantoro sebagai pengurus PPNI ( Persatuan Perawat Nasional Indonesia ) Pusat menyatakan bahwa perilaku caring sebagai kunci dalam meningkatkan mutu dan kualitas pelayanan keperawatan yang prima. Selain itu, Wiyana (2008) juga mengemukakan bahwa salah satu indikator mutu pelayanan keperawatan adalah kepuasan pasien dan caring perawat menjadi jaminan apakah layanan perawat tersebut bermutu atau tidak.

Adapun penelitian dengan judul hubungan caring dengan kepuasan pasien sampai saat ini belum pernah dilakukan di RSUD Puri Husada Tembilahan.Oleh karena itu peneliti tertarik untuk melakukan penelitian tetang "Hubungan Caring Perawat Dengan Kepuasan Pasien Di RSUD Puri Husada Tembilahan Tahun 2016"

\section{B. Rumusan Masalah}

Berdasarkan uraian latar belakang di atas, maka permasalahan yang dapat dirumuskan oleh penulis adalah "Adakah Hubungan Caring Perawat Dengan Kepuasan Pasien Di RSUD Puri Husada Tembilahan Tahun 2016?"

\section{Tujuan Penelitian}

\section{Tujuan Umum}

Untuk mengetahui hubungan caring perawat dengan kepuasan pasien di RSUD Puri Husada Tembilahan Tahun 2016

\section{Tujuan Khusus}

a. Untuk mengetahui distribusi frekuensi caring perawat di RSUD Puri Husada Tembilahan Tahun 2016.

b. Untuk mengetahui distribusi frekuensi kepuasan pasien di RSUD Puri Husada Tembilahan Tahun 2016.

c. Untuk mengetahui hubungan caring perawat dengan kepuasan pasien di RSUD Puri Husada Tembilahan Tahun 2016.

\section{Manfaat Penelitian}

\section{Aspek Teoritis}

Bagi institusi pendidikan kesehatan dapat dimanfaatkan sebagai bahan masukan untuk mengembangkan ilmu pengetahuan, bagi peneliti selanjutnya dapat melakukan dengan jenis penelitian yang berbeda.

\section{Aspek Praktis}

Dapat digunakan oleh tenaga kesehatan khususnya perawat dalam meningkatkan pelayanan kesehatan dan diharapkan dapat dijadikan sebagai bahan perencanaan dan evaluasi terhadap permasalahan yang ada.

\section{TINJAUAN KEPUSTAKAAN}

\section{A. Tinjauan Pustaka}

\section{Definisi Kepuasan Pasien}

Kepuasan adalah perasaan senang atau kecewa dari seseorang yang mendapat kesan dari membandingkan hasil pelayanan kinerja dengan harapan-harapannya. Respon ini sebagai hasil dari penilaian pasien bahwa produk/pelayanan sudah memberikan tingkat pemenuhan kenikmatan.Tingkat pemenuhan kenikmatan dan harapan ini dapat lebih atau kurang (Paparaya, 2009).

Pasien adalah orang dengan kebutuhankebutuhan yang sangat jauh berbedadari orang sehat. Kebutuhan-kebutuhannya pada saat itu bukan saja sangat menonjol tetapi mungkin sudah dalam tingkatan ekstrim. Tidak saja harus makan agar penyakitnya cepat sembuh tetapi harus disuapin. Tidak saja harus diberi obattetapi harus disertai perhatian ekstra.

Kepuasan pasien adalah suatu tingkat perasaan pasien yang timbul sebagai akibat dari 
kinerja layanan kesehatan yang diperoleh setelah pasienmembandingkannya dengan apa yang diharapkan (Imbalo, 2006).

Kepuasan pasien adalah tanggapan pasien terhadap kesesuaian tingkat kepentingan atau harapan pasien sebelum mereka menerima jasa pelayanan dengan sesudah pelayanan yang mereka terima

Kepuasan pengguna jasa pelayanan kesehatan dapat disimpulkan sebagai selisih kinerja insitusi pelayanan kesehatan dengan harapan pelanggan (pasien atau kelompok kesehatan)(Muninjaya, 2011)

Bagi pasien kebutuhan yang paling menonjol bukanlah yang berkaitan dengan harga diri atau untuk diakui kehebatannya tetapi adalah kebutuhan belongingness and social needs. Merasa dicintai, didengarkan, tidak dianggap sebagai orang yang menyusahkan saja dan tidak pula diperlakukan sebagai manusia yang tidak berguna (Tobing, 2008).

a. Aspek yang mempengaruhi kepuasan pada pasien

Menurut Purwanto (2007) aspek-aspek yang mempengaruhi kepuasan pada pasien adalah sebagai berikut:

1) Sikap pendekatan perawat pada pasien yaitu sikap staf terhadap pasien ketika pertama kali datang ke tempat pelayanan kesehatan

2) Kualitas perawatan yang diterima oleh pasien yaitu apa saja yang telah dilakukan oleh pemberi layanan kepada pasien, seberapa pelayanan kesehatan pasien selama berada di tempat pelayanan kesehatan

3) Prosedur administrasi yaitu berkaitan dengan pelayanan administrasi pasien dimulai masuk, selama perawatan berlangsung sampai ke luar dari tampat layanan kesehatan

4) Fasilitasyang disediakan disediakan tempat layanan kesehatan yaitu seperti, fasilitas ruang inap, kualitas makanan, pakaian ganti pasien, privasi dan waktu kunjungan pasien.

b. Teori Kebutuhan Abraham Maslow

Menurut Abraham Maslow, manusia memiliki lima tingkat kebutuhan hidup yang akan selalu berusaha untuk dipenuhi sepanjang masa hidupnya. Lima tingkatan yang dapat membedakan setiap manusia dari sisi kesejahteraan hidupnya, teori yang telah resmi di akui dalam dunia psikologi.

Kebutuhan tersebut berjenjang dari yang paling mendesak hingga yang akan muncul dengan sendirinya saat kebutuhan sebelumnya telah dipenuhi. Setiap orang pasti akan melalui tingkatan-tingkatan itu, dan dengan serius berusaha untuk memenuhinya, namun hanya sedikit yang mampu mencapai tingkatan tertinggi dari piramida ini.

Lima tingkat kebutuhan dasar menurut teori Maslow adalah sebagai berikut (disusun dari yang paling rendah) :

1) Kebutuhan Fisiologis

Contohnya adalah : Sandang / pakaian, pangan / makanan, papan / rumah, dan kebutuhan biologis seperti buang air besar, buang air kecil, bernafas, dan lain sebagainya.

2) Kebutuhan Keamanan dan Keselamatan Contoh seperti : Bebas dari penjajahan, bebas dari ancaman, bebas dari rasa sakit, bebas dari teror, dan semacamnya.

3) Kebutuhan Sosial

Misalnya adalah : Memiliki teman, memiliki keluarga, kebutuhan cinta dari lawan jenis, dan lain-lain.

4) Kebutuhan Penghargaan

Dalam kategori ini dibagi menjadi dua jenis, Eksternal dan Internal. Sub kategori eksternal meliputi : Pujian, piagam, tanda jasa, hadiah, dan banyak lagi lainnya. Sedangkan sub kategori internal sudah lebih tinggi dari eskternal, pribadi tingkat ini tidak memerlukan pujian atau penghargaan dari orang lain untuk merasakan kepuasan dalam hidupnya.

5) Kebutuhan Aktualisasi Diri

Tingkatan terakhir dari kebutuhan dasar Maslow adalah aktualisasi diri.Kebutuhan aktualisasi diri adalah kebutuhan yang tidak melibatkan keseimbangan, tetapi melibatkan keinginan yang terus menerus untuk memenuhi potensi.Maslow melukiskan kebutuhan ini sebagai hasrat untuk semakin menjadi diri sepenuh kemampuannya sendiri, menjadi apa saja menurut kemampuannya.Awalnya Maslow berasumsi bahwa kebutuhan untuk aktualisasi diri langsung muncul setelah kebutuhan untuk dihargai terpenuhi.Akan tetapi selama tahun 1960-an, ia menyadari bahwa banyak anak muda di Brandeis memiliki pemenuhan yang cukup terhadap kebutuhan-kebutuhan lebih rendah seperti reputasi dan harga diri, tetapi mereka belum juga bisa mencapai aktualisasi diri. 
c. Indikator Kepuasan Pasien

Salah satu indikator keberhasilan pelayanan kesehatan adalah kepuasan pasien. Kepuasan didefinisikan sebagai penilaian pasca konsumsi, bahwa suatuproduk yang dipilih dapat memenuhi atau melebihi harapan pasien, sehinggamempengaruhi proses pengambilan keputusan untuk pembelian ulang produkyang sama. Pengertian produk mencakup barang, jasa, atau campuran antarabarang dan jasa. Produk rumah sakit adalah jasa pelayanan kesehatan (Depkes RI,2008).

Supardi (2008) mengatakan model kepuasan yang komprehensif dengan fokus utama pada pelayanan barang dan jasa meliputi lima dimensi penilaian sebagai berikut :

1) Responsiveness (ketanggapan), yaitu kemampuan petugas memberikan pelayanan kepada pasien dengan cepat. Dalam pelayanan rumah sakitadalah lama waktu menunggu pasien mulai dari mendaftar sampai mendapat pelayanan tenaga kesehatan.

2) Reliability (kehandalan), yaitu kemampuan petugas memberikan pelayanan kepada pasien dengan tepat. Dalam pelayanan rumah sakit adalah penilaian pasien terhadap kemampuan tenaga kesehatan.

3) Assurance (jaminan), yaitu kemampuan petugas memberikan pelayanan kepada pasien sehingga dipercaya. Dalam pelayanan rumah sakit adalah kejelasan tenaga kesehatan memberikan informasi tentang penyakit dan obatnya kepada pasien.

4) Emphaty (empati), yaitu kemampuan petugas membina hubungan, perhatian, dan memahami kebutuhan pasien. Dalam pelayanan rumah sakit adalah keramahan petugas kesehatan dalam menyapa dan berbicara, keikutsertaan pasien dalam mengambil keputusan pengobatan, dan kebebasan pasien memilih tempat berobat dan tenaga kesehatan, serta kemudahan pasien rawat inap mendapat kunjungan keluarga/temannya.

5) Tangible (bukti langsung), yaitu ketersediaan sarana dan fasilitas fisik yang dapat langsung dirasakan oleh pasien. Dalam pelayanan rumah sakit adalah kebersihan ruangan pengobatan dan toilet.

Faktor lain yang juga digunakan oleh konsumen untuk mengukur kualitas jasa adalah outcome, process, dan image dari jasa tersebut. Menurut Gronroos, ketiga kriteria tersebut dijabarkan menjadi enam unsur :

\section{1) Professionalism and skills}

Di bidang pelayanan kesehatan, kriteria ini berhubungan dengan outcome, yaitu tingkat kesembuhan pasien. Pelanggan menyadari bahwa jasa pelayanan kesehatan dihasilkan oleh SDM yang memiliki pengetahuan dan keterampilan profesional yang berbeda. Institusi penyedia pelayanan kesehatan harus menjamin reputasi dokter dan petugas keehatan lainnya yang bekerja pada institusi pelayanan kesehatan tersebut. Dokter dan petugas kesehatan menjadi faktor produksi utama yang akan menentukan hasil (outcome) pelayanan kesehatan, termasuk yang akan menjamin tingkat kepuasan pada penggunanya.

2) Attitudes and behaviour

Kriteria sikap dan perilaku staf akan berhubungan dengan proses pelayanan. Pelanggan institusi jasa pelayanan kesehatan akan merasakan kalau dokter dan paramedis rumah sakit sudah melayani mereka dengan baik sesuai SOP pelayanan. Situasi ini ditunjukkan oleh sikap dan perilaku positif staf yang akan membantu para pengguna pelayanan kesehatan mengatasi keluhan sakitnya.

3) Accessibility and flexibility

Kriteria penilaian ini berhubungan dengan proses pelayanan. Pengguna jasa pelayanan akan merasakan bahwa institusi penyedia pelayanan jasa, lokasi, jam kerja, dan sistemnya dirancang dengan baik untuk memudahkan para pengguna mengakses pelayanan sesuai dengan kondisi pengguna jasa (fleksibilitas), yaitu sesuai dengan keadaan sakit pasien, jarak yang harus ditempuh, tarif pelayanan, dan kemampuan ekonomi pasien atau keluarga untuk membayar tarif pelayanan.

\section{4) Reliability and trustworthiness}

Kriteria penilaian ini juga berhubungan dengan proses pelayanan. Pengguna jasa pelayanan kesehatan bukan tidak memahami risiko yang mereka hadapi jika memilih jasa pelayanan yang ditawarkan oleh dokter.

5) Recovery

Kriteria penilaian ini juga berhubungan dengan proses pelayanan. Pelanggan memang menyadari kalau ada kesalahan atau risiko akibat tindakan medis yang diambil, tetapi para pengguna jasa pelayanan mempercayai bahwa institusi penyedia jasa 
pelayanan sudah melakukan perbaikan (recovery) terhadap mutu pelayanan yang ditawarkan kepada publik untuk mengurangi risiko medis yang akan diterima pasien.

6) Reputation and credibility

Kriteria ini berhubungan dengan image. Pelanggan akan menyakini benar bahwa institusi penyedia jasa pelayanan kesehatan memang memiliki reputasi baik, dapat dipercaya, dan punya nilai (rating) tinggi di bidang pelayanan kesehatan. Kepercayaan ini sudah terbukti dari reputasi pelayanan yang sudah ditunjukkan selama ini oleh institusi penyedia jasa pelayanan kesehatan ini.

Indikator mutu untuk mengukur kepuasan pasien yang dirawat di Rumah Sakit (RS) :

1) Jumlah dan jenis keluhan pasien dan keluarganya

2) Surat keluhan pembaca di Koran

3) Surat kaleng

4) Survei oleh lembaga survei independen untuk mengetahui tingkat kepuasan pengguna jasa pelayanan RS

5) Menanyakan kepuasan pengguna pelayanan kesehatan melalui telepon, dan sebagainya.

Indikator mutu pelayanan untuk mengukur tingkat efisiensi pelayanan RS :

1) Unit cost rawat jalan RS

2) Jumlah penderita yang mengalami decubitus

3) Jumlah penderita yang jatuh dari tempat tidur

4) BOR ( Bed Occupation Rate - tingkat hunian $\mathrm{RS})$

5) BTO (Bed Turn Over)

6) TOI ( Turn Over Interval )

7) ALOS (Average Length Of Stay)

8) Normal Tissue Removal Rate (Muninjaya, 2013)

d. Cara Mengukur Kepuasan Pasien

Dalam penelitian ini untuk mengukur kepuasan pasien yaitu menggunakan skala likert. Skala likert digunakan untuk mengukur sikap, pendapat dan persepsi seseorang atau sekelompok orang tentang fenomena sosial.

Jawaban setiap item instrumen yang menggunakan skala likert mempunyai gradasi dari sangat positif sampai sangat negatif, yang dapat berupa kata-kata.

Untuk keperluan analisis kuantitaf, maka jawaban itu dapat diberi skor, misalnya mengukur kepuasan pasien digunakan lima kriteria yaitu nilai 1 jika sangat tidak puas, 2 jika tidak puas, 3 jika cukup puas, 4 jika puas dan 5 jika sangat tidak puas (Hasmi, 2012). Pada pengkatagorian puas dan tidak puas, dihitung nilai rata-rata dari jumlah responden. Pada katagori puas jika nilai $\geq$ mean dan tidak puas jika $<$ mean

\section{Caring Perawat}

a. Pengertian Caring Secara Umum

Caring merupakan fenomena universal yang berkaitan dengan cara seseorang berfikir, berperasaan dan bersikap ketika berhubungan dengan orang lain (Priyoto, 2015)

Caring merupakan pengikat seluruh subsistem keperawatan, hal ini sesuai dengan pendapat yang mengemukakan "Caring is the essence of nursing and the unique and unifying foccus of the profession"

pendapat ini berarti bahwa caring merupakan komponen inti keperawatan (Samba, 2014)

Selain itu, caring dapat diartikan sebagai suatu kemampuan untuk berdedikasi bagi orang lain, pengawasan dengan waspada, perasaan empati pada orang lain dan perasaan cinta atau menyayangi. Caring adalah sentral untuk praktik keperawatan karena caring merupakan suatu cara pendekatan yang dinamis, dimana perawat bekerja untuk lebih meningkatkan kepeduliannya kepada klien (Sudarta, 2015)

b. Paradigma Caring

1) Keperawatan

Keperawatan adalah penepatan art dan human science melalui interaksi transpersonal caring untuk membantu manusia mencapai keharmonisan fikiran, jiwa dan raga yang menimbulkan selfknowlegde, selfcontrol, selfcare, dan selfhealing

2) Klien

Klien adalah individu atau kelompok yang mengalami ketidakharmonisan pikiran, jiwa dan raga, yang membutuhkan bantuan terhadap pengambilan keputusan tentang kondisi sehat-sakitnya untuk meningkatkan keharmonisan, selfcontrol, pilihan dan selfdetermination

3) Kesehatan

Kesehatan adalah kesatuan dan keharmonisan didalam fikiran, jiwa dan raga 
antara diri dengan orang lain dan antara diri dengan lingkungan.

4) Lingkungan

Lingkungan adalah dimana interaksi transpersonal caring terjadi antara klien dan perawat (Sudarta, 2015)

c. Konsep Caring menurut Para Ahli Keperawatan

1) Teori Caring Menurut Watson

Watson, 2009, mengemukakan bahwa caring adalah esensi dari keperawatan yang membedakan dengan profesi yang lain dan mendominasi serta mempersatukan tindakan - tindakan keperawatan. Terdapat 10 faktor sebagai "human caring" yang diperlukan dalam hubungan antara perawat pasien. Faktor tersebut diidentifikasikan melalui hasil penelitian mengenai faktor-faktor yang diperlukan dalam hubungan therapeutik dari tenaga kesehatan :

1. Memiliki nilai altruistic (sifat lebih memperhatikan dan mengutamakan kepentingan orang lain) dan mencintai sesama.

2. Memiliki kemampuan untuk menanamkan keyakinan, harapan dan menghargai sesama.

3. Memiliki kemampuan untuk menumbuhkan kepekaan terhadap diri dan orang lain.

4. Memiliki kemampuan dalam membina hubungan saling percaya, saling membantu dan peduli.

5. Memiliki kemampuan dalam menerima ungkapan perasaan positif dan negatif.

6. Memiliki kemampuan dalam menggunakan metode penyelesaian masalah dengan sistematis untuk pengambilan keputusan.

7. Memiliki kemampuan untuk meningkatkan proses belajar mengajar ilmiah sesuai kebutuhan individu.

8. Menyediakan lingkungan yang aman dan melindungi meliputi kebutuhan fisik, mental, sosial, budaya dan spiritual.

9. Membantu pemenuhan kebutuhan manusia.
10. Terbuka terhadap hal - hal yang tidak terduga (Kusmiran, 2015)

Dalam hal ini caring merupakan perwujudan dari semua faktor yang digunakan perawat dalam memberikan pelayanan kesehatan pada klien. Kemudian caring juga menekankan harga diri individu artinya dalam melakukan praktik keperawatan, perawat senantiasa selalu menghargai klien dengan menerima kelebihan maupun kekurangan klien (Sudarta, 2015)

Asumsi dasar teori watson terletak pada 7 asumsi dasar yang menjadi kerangka kerja dalam pengembangan teori, yaitu:

a) Caring dapat dilakukan dan dipraktikan secara interpersonal.

b) Caring meliputi faktor-faktor karatif yang dihasilkan dari kepuasan terhadap pemenuhan kebutuhan dasar manusia.

c) Caring yang efektif akan meningkatkan status kesehatan dan perkembangan individu dan keluarga.

d) Respon caring adalah menerima seseorang tidak hanya sebagai seseorang berdasarkan saat ini tetapi seperti apa dia mungkin akan menjadi dimasa depannya.

e) Caring environment, menyediakan perkembangan potensi dan memberikan keluasan memilih kegiatan yang terbaik bagi diri seseorang dalam waktuyang telah ditentukan.

f) Caring bersifat healthogenic. Praktek caring mengitegrasikan pengetahuan biopisikal dan perilaku manusia untuk meningkatkan kesehatan dan untuk membantu pasien yang sakit.

g) Caring merupakan inti dari keperawatan (Priyoto, 2015)

2) Teori caring menurut Kristin Swanson Kristin Swanson mendefinisikan peduli sebagai, "cara mengasuh yang berkaitan dengan lainnya dihargai, menuju yang satu merasa rasa komitmen pribadi dan tanggung jawab". Swanson mendefinisikan 
caring sebagai cara memelihara hubungan dengan nilai lain, kepada seseorang yang merasa sebagai pribadi yang sadar akan komitmen dan tanggung jawab.

Lima proses caring menurut Swanson

a) Knowing:Menghindari asumsi, berpusat pada orang diperhatikan, menilai secara menyeluruh, mencari petunjuk, terlibat baik.

b) Being with :Berada di sana, menyampaikan

kemampuan,berbagi perasaan, tidak membebani.

c) Doing for : Menghibur, mengantisipasi, melakukan terampil, melindungi, menghargai martabat.

d) Enabling : Menginformasikan / menjelaskan, mendukung / memungkinkan, fokus, menghasilkan alternatif, memvalidasi / umpan balik.

e) Maintaining Beliefe : percaya, memegang dalam diri, mempertahankan harapan-penuh sikap, menawarkan optimism yang realistis, "going the distance" (Sudarta, 2015)

d. Pentingnya Aplikasi Caring

Bersikap caring sebagai media pemberi asuhan perawat merupakan "caring for" (merawat) dan "caring about" (peduli) pada orang lain. "caring for" adalah kegiatan-kegiatan dalam memberikan asuhan keperawatan saperti mengatur pemberian obat, prosedurprosedur perawatan, membantu memenuhi kebutuhan dasar klien seperti membantu dalam pemberian makanan. "caring about" berkaitan dengan kegiatan-kegiatan sharing atau membagi pengalaman-pengalaman seseorang dan keberadaannya. Perawat perlu menampilkan sikap empati, jujur dan tulus dalam melakukan caring about. Kegiatan perawat harus ekspresif dan merupkan cerminan aktivitas yang menciptakan hubungan dengan klien. Sifat-sifat aktivitas ini menimbulkan keterlibatan hubungan saling percaya (Priyoto, 2015)

\section{e. Aplikasi Caring Dalam Praktek} Keperawatan

Lynda Hall mengemukakan sebagai seorang perawat, kemampuan care, core, dan cure harus dipadukan secara seimbang sehingga menghasilkan asuhan keperawatan yang optimal untuk klien.

Dalam melakukan asuhan keperawatan yang harus dillakukan mencakup, sikap caring, hubungan perawat klien yang terapeutik, kolaborasi dengan anggota tim kesehatan lain, kemampuan dalam memenuhi kebutuhan klien, kegiatan jaminan mutu pelayanan. Aplikasi caring perawat seperti memperkenalkan diri serta membuat kontak hubungan, memanggil klien dengan namanya, menggunakan sentuhan, mengkaji lebih lanjut keinginan klien, meyakinkan klien bahwa perawat akan membantu klien dalam memberikan asuhan keperawatan, memenuhi kebutuhan dasar klien dengan iklas, menjelaskan setiap tindakan yang akan dilakukan, mendengarkan dengan penuh perhatian, bersikap jujur, bersikap empati, dapat mengendalikan perasaan, selalu mendahulukan kepentingan klien, tidak menerima uang dari klien, memberi waktu dan perhatian, bekerja dengan terampil, dan cermat berdasarkan ilmu, kompeten dalam melakukan tindakan keperawatan, berespon dengan cepat dan tanggap, mengidentifikasi secara dini perubahan status kesehatan klien, serta memberikan rasa aman dan nyaman (Priyoto, 2015)

f. Proses Keperawatan Dalam Teori Caring

Watson (1979) menekankan bahwa proses keperawatan memiliki langkahlangkah yang sama dengan proses riset ilmiah, karena kedua proses tersebut mencoba untuk menyelesaikan masalah dan menemukan solusi yang terbaik. Lebih lanjut Watson menggambarkan kedua proses tersebut sebagai berikut: Pengkajian

Meliputi observasi, identifikasi, dan review masalah; menggunakan pengetahuan dari literature yang dapat diterapkan, melibatkan pengetahuan konseptual untuk pembentukan dan konseptualisasi kerangka kerja yang digunakan untuk memandang dan 
mengkaji masalah danpengkajian juga meliputi pendefinisian variabel yang akan diteliti dalam memecahkan masalah.

1) Perencanaan

Perencanaan membantu untuk menentukan bagaimana variablevariabel akan diteliti atau diukur, meliputi suatu pendekatan konseptual atau desain untuk memecahan masalah yang mengacu pada asuhan keperawatan serta meliputi penentuan data apa yang akan dikumpulkan dan pada siapa dan bagaimana data akan dikumpulkan.

2) Implementasi

Merupakan tindakan langsung dan implementasi dari rencana serta meliputi pengumpulan data.

3) Evaluasi

Merupakan metode dan proses untuk menganalisa data, juga untuk meneliti efek dari intervensi berdasarkan data serta meliputi interpretasi hasil, tingkat dimana suatu tujuan yang positif tercapai, dan apakah hasil tersebut dapat digeneralisasikan (Sudarta, 2015)

g. Cara Mengukur Caring Perawat

Dalam penelitian ini untuk mengukur Caring Perawat yaitu menggunakan skala likert. Skala likert digunakan untuk mengukur sikap, pendapat dan persepsi seseorang atau sekelompok orang tentang fenomena sosial.

Jawaban setiap item instrumen yang menggunakan skala likert mempunyai gradasi dari sangat positif sampai sangat negatif, yang dapat berupa kata-kata.

Untuk keperluan analisis kuantitaf, maka jawaban itu dapat diberi skor, misalnya mengukur caring perawat digunakan empat kriteria yaitu nilai 1 jika sangat tidak setuju, 2 jika tidak setuju, 3 jika setuju dan 4 jika sangat setuju (Hasmi, 2012). Pada pengkatagorian caring dan tidak caring, dihitung nilai rata-rata dari jumlah responden. Pada katagori caring jika nilai $\geq$ mean dan tidak caring jika > mean

\section{Penelitian Terkait}

Pada penelitian Niken (2013) dengan judul "Upaya Peningkatan Caring Perawat Terhadap Kepuasan Pasien Di ruang Rawat Inap RS Permata Medika Semarang" menunjukkan adanya hubungan antara caring perawat dengan kepuasan pasien $(\mathrm{p}=$ 0,$015 ; \quad \alpha$ 0,05). Perawat yang caring mempunyai peluang 4,92 kali untuk memberikan kepuasan pasien dibanding yang kurang caring. Perilaku caring perawat dijadikan penilaian kinerja untuk memenuhi kepuasan pasien.

Abdul (2013) dengan judul "Hubungan Perilaku Caring Perawat Dengan Tingkat Kepuasan Pasien Rawat Inap Rumah Sakit". Hasil penelitian menunjukkan bahwa ada hubungan signifikan antara perilaku caring perawat dengan tingkat kepuasan pasien rawat inap. Uji fisher menunjukkan $p=$ 0,000. Dapat disimpulkan bahwa ada hubungan yang signifikan antara perilaku caring perawat dengan tingkat kepuasan pasien rawat inap rumah sakit.

Adapun perbedaan penelitian ini dengan penelitian sebelumnya dapat dilihat dari besarnya hubungan caring perawat dengan kepuasan pasien yaitu penelitian sebelumnya mempunyai peluang 4,92 kali untuk memberikan kepuasan pasien dibanding yang kurang caring dan Uji Fisher yang dilakukan untuk menunjukkan ada hubungan atau tidak, sedangkan penelitian ini mendapatkan nilai 0,316 untuk melihat besarnya hubungan caring perawat dan menggunakan uji chi square.

\section{B. Kerangka Teori}

Kerangka teori merupakan rangkaian teori yang mendasari topik penelitian. Berdasarkan uraian tinjauan teori di atas tentang caring perawat yang secara hipotesis berhubungan dengan kepuasan pasien, maka ditunjukan kerangka teori pada skema 2.1 sebagai berikut
10 faktor sebagai "human caring" yang diperlukan dalam hubungan antara perawat pasien menurut Watson :

1. Memiliki nilai altruistic (sifat lebih memperhatikan dan mengutamakan kepentingan orang lain) dan mencintai sesama.

Jurnal 2. Memiliki kemampuan untuk menanamkan keyakinan, harapan dan menghargai sesama.

3. Memiliki kemampuan untuk menumbuhkan kepekaan terhadap diri dan orang lain.

4. Memiliki kemampuan dalam membina hubungan saling percaya, saling membantu dan 
Lima proses caring menurut Swanson :

1. Knowing: Menghindari asumsi, berpusat pada orang diperhatikan, menilai secara menyeluruh, mencari petunjuk, terlibat baik.

2. Being with : Berada di sana, menyampaikan kemampuan,berbagi perasaan, tidak membebani.

3. Doing for : Menghibur, mengantisipasi, melakukan terampil, melindungi, menghargai martabat.

4. Enabling : Menginformasikan / menjelaskan, mendukung / memungkinkan, fokus, menghasilkan alternatif, memvalidasi / umpan balik.

5. Maintaining Beliefe : percaya, memegang dalam diri, mempertahankan harapan-penuh sikap, menawarkan optimisme yang realistis,"going the distance".

Sumber :Sudarta, 2015

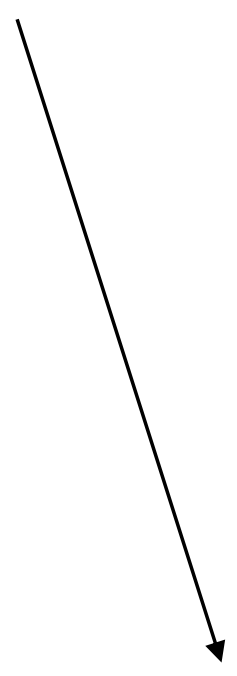

Kepuasan pasien :

1. Ketanggapan

2. Kehandalan

3. Jaminan

4. Empati

5. Bukti langsung Sumber : Suparti, 2008

Skema 2.1 kerangka teori 


\section{Kerangka Konsep}

Kerangka konsep merupakan suatu hubungan atau kaitan antara konsep satu terhadap konsep yang lainnya dari masalah yang ingin diteliti (Setiadi, 2013). Dengan demikian kerangka konsep sebagai berikut:

Variabel Independen

Variabel Dependen

Caring Perawat

Kepuasan Pasien

\section{Skema 2.2 Kerangka Konsep}

\section{Hipotesis}

Hipotesis merupakan dugaan sementara dari jawaban rumusan masalah penelitian.Adapun hipotesis dari penelitian ini adalah :

$\mathrm{H}_{\mathrm{a}}$ : Ada hubungan caring perawat dengan kepuasan pasien di RSUD Puri Husada Tembilahan Tahun 2016

\section{BAB IV \\ HASIL PENELITIAN}

Penelitian ini bertujuan untuk menganalisis hubungan caring perawat

Tabel 4.1 : Distribusi Frekuensi Berdasarkan Caring Perawat di RSUD Puri Husada Tembilahan Tahun 2016.

\begin{tabular}{|c|c|c|c|}
\hline \multirow{2}{*}{ No } & \multirow{2}{*}{ Caring Perawat } & \multicolumn{2}{|c|}{$\begin{array}{l}\text { Jumlah } \\
\end{array}$} \\
\hline & & Frekuensi (n) & Persentase $(\%)$ \\
\hline 1 & Caring Baik & 88 & 69,3 \\
\hline 2 & Caring Kurang & 39 & 30,7 \\
\hline & Total & 127 & 100 \\
\hline
\end{tabular}

Dari Tabel 4.1 diatas, dapat diketahui bahwa dari 127 responden, terdapat 88

Tabel 4.2 : Distribusi Frekuensi Berdasarkan Kepuasan Pasien di RSUD Puri

\begin{tabular}{clccc}
\hline \multirow{2}{*}{ No } & \multirow{2}{*}{ Kepuasan Pasien } & \multicolumn{2}{c}{ Jumlah } \\
\cline { 3 - 4 } & & Frekuensi (n) & Persentase (\%) \\
\hline 1 & Puas & 44 & 66,1 \\
2 & Tidak Puas & 43 & 33,9 \\
\hline \multicolumn{2}{c}{ Total } & $\mathbf{1 2 7}$ & $\mathbf{1 0 0}$ \\
\hline
\end{tabular}

Dari Tabel 4.2 diatas, dapat diketahui bahwa dari 127 responden, terdapat 84 $(66,1 \%)$ responden menyatakan puas. dengan kepuasan pasien di RSUD Puri Husada Tembilahan Tahun 2016. Pengumpulan data pada penelitian ini dimulai dari tanggal 04 s/d 25 April 2016. Pada bab ini akan diuraikan hasil penelitian setiap variabel melalui analisis univariat dan bivariat.

\section{A. Analisis Univariat}

Analisis univariat pada penelitian ini dilakukan untuk mengetahui distribusi frekuensi dari variabel yang diteliti, diantaranya caring perawat dan kepuasan pasien. Masing-masing distribusi frekuensi pada penelitian ini dapat dilihat pada tabel di bawah ini :
$(69,3 \%)$ responden menyatakan bahwa caring perawat adalah baik.

\section{Husada Tembilahan Tahun 2016.}




\section{B. Analisis Bivariat}

Analisis bivariat pada penelitian ini dilakukan untuk menganalisis hubungan variabel yang diteliti. Masing-masing analisisnya pada penelitian ini dapat dilihat pada tabel di bawah ini :

Tabel 4.3 : Hubungan Caring Perawat dengan Kepuasan Pasien di RSUD Puri Husada Tembilahan Tahun 2016.

\begin{tabular}{|c|c|c|c|c|c|c|c|c|c|c|}
\hline \multirow[t]{3}{*}{ No } & \multirow{3}{*}{$\begin{array}{l}\text { Caring } \\
\text { Perawat }\end{array}$} & \multicolumn{4}{|c|}{ Kepuasan Pasien } & \multirow{2}{*}{\multicolumn{2}{|c|}{ Jumlah }} & \multirow{2}{*}{$\begin{array}{c}P \\
\text { Value }\end{array}$} & \multirow[t]{2}{*}{ POR } & \multirow{2}{*}{$\begin{array}{c}\text { CI } \\
(\mathbf{9 5 \%})\end{array}$} \\
\hline & & \multicolumn{2}{|c|}{ Puas } & \multicolumn{2}{|c|}{$\begin{array}{l}\text { Tidak } \\
\text { Puas }\end{array}$} & & & & & \\
\hline & & $\mathbf{n}$ & $\%$ & $\mathbf{n}$ & $\%$ & $\mathbf{n}$ & $\%$ & & & \\
\hline 1 & Caring Baik & 52 & 59,1 & 36 & 40,9 & 88 & 100 & 0,020 & 0,316 & $0,126-$ \\
\hline 2 & $\begin{array}{l}\text { Caring } \\
\text { Kurang } \\
\end{array}$ & 32 & 82,1 & 7 & 17,9 & 39 & 100 & & & 0,794 \\
\hline & Jumlah & 84 & 66,1 & 43 & 33,9 & 127 & 100 & & & \\
\hline
\end{tabular}

Ket :Hasil penelitian dilakukan dengan uji statistik Chi Square

Dari tabel 4.3 dapat dilihat bahwa dari 88 responden yang menyatakan caring perawat baik , sebanyak 36 responden (40,9\%) menyatakan tidak puas. Sedangkan dari 39 responden yang menyatakan caring perawat kurang, sebanyak 32 responden $(82,1 \%)$ menyatakan puas. Hasil uji statistik diperoleh nilai $p$ value $=0,020$ maka dapat disimpulkan bahwa ada hubungan yang bermakna antara caring perawat dengan kepuasan pasien di RSUD Puri Husada Tembilahan Tahun 2016. Nilai POR 0,316 (CI $\pm 95 \%$ : 0,126-0,794) artinya pasien yang puas memiliki risiko 0,3 kali mendapatkan caring baik dari perawat.

\section{BAB V}

\section{PEMBAHASAN}

\section{A. Hubungan Caring Perawat Dengan Kepuasan Pasien di RSUD Puri Husada Tembilahan Tahun 2016.}

Dari hasil hubungan antara caring perawat dengan kepuasan pasien diperoleh bahwa ada sebanyak $36(40,9 \%)$ perawat yang caring baik pasiennya tidak puas, sedangkan diantara perawat yang caring kurang ada $32(82,1 \%)$ pasien puas. Hasil uji statistik diperoleh nilai $p$ value $=0,020$ maka dapat disimpulkan ada perbedaan proporsi pasien tidak puas antara perawat yang caring baik dengan caring kurang yang artinya terdapat hubungan caring perawat dengan kepuasan pasien di RSUD Puri Husada Tembilahan Tahun 2016. Nilai POR 0,316 (CI $\pm 95 \%: 0,126-0,794)$ artinya pasien yang puas memiliki risiko 0,3 kali mendapatkan caring baik dari perawat.

Hasil penelitian ini diketahui bahwa ketidakpuasan pasien terhadap pelayanan yang diberikan selama menjalani perawatan di RSUD Puri Husada karena caring perawat yang masih kurang pada pasien. Kejadian yang membuat ketidakpuasan pasien terhadap pelayanan antara lain $(44,9 \%)$ perawat sebelum melakukan tindakan tanpa menjelaskan kepada pasien, $(35,4 \%)$ perawat menolak kunjungan keluarga pasien yang ramai, $(35,4 \%)$ perawat menunjukkan ketidakpedulian mengenai keluhan pasien, $(33,1 \%)$ perawat berbicara dengan suara keras dan tegas, $(29,1 \%)$ perawat memperlakukan pasien sebagai objek. Dengan demikian pasien merasa tidak puas selama mendapatkan perawatan di rumah sakit.

Penelitian ini didapatkan caring baik sebesar $52(59,1 \%)$ pasien yang puas dan caring baik sebesar $36(40,9 \%)$ pasien tidak puas dengan pelayanan yang diberikan oleh perawat. Adapun ketidakpuasan pasien terhadap pelayanan disebabkan oleh beberapa faktor, antara lain fasilitas yang disediakan tempat layanan kesehatan yaitu seperti, fasilitas ruang inap, kualitas makanan, pakaian ganti pasien, privasi dan waktu kunjungan pasien.Status ekonomi pasien yang mampu menginginkan pelayanan yang lebih, keluarga yang memiliki masalah pribadi, lingkungan rumah sakit yang tidak tenang, harga diri pasien di dalam 
masyarakat yang tinggi sehingga menginginkan pelayanan yang lebih dari perawat.

Hasil penelitian ini sejalan dengan penelitian yang dilakukan oleh Hidayati (2013) dengan judul "Hubungan perilaku caringperawat dengan tingkat kepuasan pasien rawat inap di rumah sakit PKU Muhammadiyah Surakarta". Dengan nilai $p$ value 0,000 menyimpulkan bahwa terdapat hubungan yang signifikan perilaku caring perawat terhadap tingkat kepuasan pasien rawat inap di Rumah Sakit PKU Muhammadiyah Surakarta, yaitu semakin baik perilaku caring perawat, maka semakin puas pasien dengan pelayanan yang diberikan perawat.

Caring adalah asuhan yang diberikan secara terus menerus difokuskan pada perawatan fisik maupun mental dan meningkatkan rasa kepuasan pasien. Perawat dalam meningkatkan asuhan keperawatan untuk kebutuhan rasa kepuasan pasien hendaknya menerapkan penggunaan caring.

Caring adalah memberikan perhatian penuh pada pasien saat memberikan asuhan keperawatan. Asuhan keperawatan adalah sesuatu yang dikerjakan kepada seseorang atau memberikan informasi kepada seseorang dengan tujuan untuk memenuhi kebutuhan, meningkatkan atau mengembalikan kemampuan membantu diri sendiri, atau menghilangkan gangguan. Metode pemecahan masalah asuhan keperawatan salah satunya dengan menggunakan proses keperawatan. Proses keperawatan salah satunya adalah metode yang sistematik dan rasional dalam merencanakan dan memberikan pelayanan keperawatan kepada individu dengan tujuan untuk mengidentifikasi status kesehatan klien, kebutuhan atau masalah kesehatan aktual atau risiko, membuat perencanaan sesuai dengan kebutuhan yang telah diidentifikasi, dan melaksanakan intervensi keperawatan spesifik sesuai dengan kebutuhan (Potter, 2006).

Pemberian asuhan keperawatan harus diciptakan hubungan yang baik antara pasien dan perawat. Hubungan perawat dengan pasien menjadi inti dalam pemberian asuhan keperawatan, karena keberhasilan penyembuhan, peningkatan kesehatan pasien dan kepuasan pasien sangat dipengaruhi oleh hubungan perawat dengan pasien. Metode pemberian asuhan keperawatan harus memfasilitasi efektifnya hubungan tersebut. Konsep yang mendasari hubungan perawat pasien adalah hubungan saling percaya, empati, caring, otonomi, dan mutualitas.

Untuk menciptakan sebuah kepuasan pasien kepada perawat adalah dengan menciptakan waktu bersama perawat dan pasien. Perawat yang berhasil adalah membangun kepercayaan akan membuat pekerjaan perawat menjadi lebih mudah karena pasien yang percaya akan menerima seluruh kegiatan yang dilakukan oleh perawat dalam memberikan pelayanan askep untuk pemenuhan kepuasan pasien,selain itu aspek penting yang harus diciptakan untuk menciptakan hubungan baik antara pasien dan perawat adalah menciptakan kondisi perawat yang seimbang dalam beban kerjanya sehingga perawat terhindar dari kejenuhan dan kelelahan yang berlebihan (Jones, 2009)

Dampak perilaku caring bagi perawat adalah dapat menjaga martabat dan integritas pasien, meningkatkan status pemulihan pasien, menurunkan gejala yang dirasakan pasien, meningkatkan status pemulihan pasien, menurunkan gejala yang dirasakan pasien, meningkatkan kepuasan pasien serta terciptanya kualitas pelayanan keperawatan yang tinggi.

Dampak perilaku perawat yang caring yaitu meningkatkan kesejahteraan emosi dan spiritual, meningkat hubungan saling percaya, meningkatkan penyembuhan fisik, keamanan, memiliki lebih banyak energi, biaya perawatan lebih rendah serta menimbulkan perasaan lebih nyaman. Perilaku caring yang ditunjukkan untuk memenuhi rasa puas masih kurang yang dipersepsikan oleh pasien karena terkait dengan hubungan antara pasien dan perawat yang kurang, baik secara kualitas maupun kuantitasnya. Hubungan secara kualitas dapat diwujudkan dengan adanya komunikasi dan proses keperawatan dalam menyelesaikan masalah pasien, sedangkan kuantitas sering atau tidaknya perawat membina hubungan dengan pasien. Perawat belum banyak menerapkan komunikasi terapeutik kepada pasien pada setiap praktik keperawatan, sekaligus bahwa komunikasi merupakan hal penting yang harus diterapkan dalam praktik keperawatan sebab komunikasi merupakan alat untuk membangun suatu hubungan yang 
terapeutik. Selain itu komunikasi bisa menjadi media untuk mempengaruhi perilaku orang lain, sehingga tanpa komunikasi, hubungan terapeutik perawat pasien tidak mungkin terjalin. Komunikasi yang efektif merupakan salah satu hubungan saling percaya. Perawat berada pada posisi yang ideal untuk memberikan informasi, pendidikan kesehatan, dorongan dan dukungan kepada pasien dalam rangka memandirikan dan melibatkan pasien dalam mencapai kondisi kesehatannya yang optimal (Watson, 2009).

\section{BAB VI}

\section{PENUTUP}

\section{A. Simpulan}

Sesuai dengan hipotesa penelitian didapat $\mathrm{p}$ value $0,020<0,005$ maka dapat disimpulkan bahwa terdapat hubungan caring perawat dengan kepuasan pasien di RSUD Puri Husada Tembilahan Tahun 2016. POR 0,319, artinya bahwa pasien yang diberi perilaku caring baik oleh perawat akan berpeluang 0,319 kali lebih puas.

\section{B. Saran}

Berdasarkan kesimpulan yang telah dibuat ada beberapa saran yang ingin disampaikan oleh peneliti yaitu:

1. Bagi Institusi Rumah Sakit Umum Daerah Puri Husada

a. Agar dapat memasukkan peningkatan perilaku caring perawat dalam pemberian rasa kepuasan ke dalam perencanaan dan tujuan pelayanan keperawatan sekaligus dibuat kebijakan terkait caring dan rasa kepuasan pasien

b. Menjadikan aspek caring dalam salah satu penilaian evaluasi penampilan kerja perawat dan program orientasi staf baru

c. Menyusun jadwal dinas bagi perawat dengan tepat sesuai dengan kebutuhan pelayanan supaya tidak ada perawat yang merasa kecapian atau kelelahan sehingga memberikan dampak perawat tidak menerapkan perilaku caring ataupun pemberian rasa kepuasan pada pasien. d. Memberikan orientasi bagi staf baru mengenai kebijakan, aturan maupun standar kepuasan pasien yang harus ditaati dalam bekerja

2. Bagi peneliti selanjutnya

Diharapkan kepada peneliti selanjutnya untuk mencari faktor penyebab lain terjadinya ketidakpuasan pasien dalam mendapatkan pelayanan kesehatan.

\section{DAFTAR PUSTAKA}

Arikunto. (2010). Prosedur Penelitian Suatu Pendekatan Praktik. Jakarta : PT Rineka Cipta

Blais. (2007). Praktek Peperawatan Profesional . Edisi 4 . Jakarta : EGC

Depkes RI. (2008). Standar Pelayanan Minimal Rumah Sakit. Jakarta : Bhakti Husada

Dwidiyanti, (2007). Caring Kunci Sukses Perawat/Ners Mengamalkan Ilmu. Semarang : Hasani

Hidayat, Aziz Alimul. (2014). Riset Keperawatan dan Tehnik Penelitian Ilmiah. Jakarta: Salemba Medika

Imbalo. (2006). Managemen Pelayanan Kesehatan. Jakarta : EGC

Kusmiran, Eny. (2015). Soft Skills Caring Dalam Pelayanan Keperawatan. Jakarta : TIM

Muhasidah. (2002). Hubungan Tehnik dan Frekuensi Supervise Kepala ruangan dengan pelaksanaan caring untuk perawat pelaksana di RS Sumber Waras. Tesis. Program Pascasarjana FIK UI. Jakarta; Tidak dipublikasikan

Muninjaya, A.A. Gde (2011). Manajemen Mutu Pelayanan Kesehatan. Jakarta : EGC

Nurachmah (2001 ). Asuhan Keperawatan Bermutu di Rumah Sakit. Perhimpunan rumah sakit seluruh Indonesia (PERSI).

Paparaya. (2009). Manajemen Keperawatan. Yogyakarta : Numed

Potter, P.A \& Perry (2006). Fundamental of nursing concept; Process \&Practice. St. Louis : Mosby

Priyoto. (2015). Komunikasi \& Sikap Empati Dalam Keperawatan. Yogyakarta : Graha Ilmu

Profil Rumah Sakit Umum Daerah Puri Husada Tembilahan (2016)

Purwanto. (2007). Pengadaan Layanan Kesehatan. Yogyakarta: Gosyen Publising 
Rahayu. (2001). Faktor-faktor yang berhubungan dengan sikap caring yang di persepsikan oleh perawat pelaksana di ruang rawat inap RSUP Persahabatan. Jakarta : Tesis

Samba, Suharyati. (2014). Nursing Center Konsep \& Aplikasi. Jakarta : EGC

Saryono (2010). Kumpulan Instrumen Penelitian Kesehatan. Bantul : Nuha Medika

Saryono dan Ari Setiawan. (2010). Metodologi Penelitian. Yogyakarta : Nuha Medika

Setiadi. (2013). Konsep dan Praktik Penulisan Riset Keperawatan. Yogyakarta : Graha Ilmu

Sitorus. (2007). Model Praktek Keperawatan Profesional di Rumah Sakit. Jakarta : EGC .

Sudarta, I Wayan. (2015). Managemen Keperawatan Penerapan Teori Model Dalam Pelayanan Keperawaran. Yogyakarta : Gosyen Publising

Sujarweni, V Wiratna. (2014). Metodologi Penelitian Keperawatan. Yogyakarta : Gava Media

Tobing. (2008). Hubungan Kepuasan dan Harapan Pasien Dengan Mutu Pelayanan Di Instalasi Rawat Jalan RSU DR. Soetomo. Surabaya : Tidak dipublikasikan

Uliyah, Musrifatul. (2008). Keterampilan Dasar Klinik. Jakarta : Salemba Medika

Wijono. (2007). Manajemen Mutu Pelayanan Kesehatan, Teori, Strategi dan Aplikasi. Jakarta : Salemba

Wiyana. (2008). Membangun Pribadi Caring Perawat. Jakarta : Graha Ilmu

Wulan \& Hastuti. (2011). Pengantar Etika Keperawatan. Jakarta : Prestasi Pustaka.

Yuslizar (2001) Faktor-faktor yang berhubungan dengan kepuasan pasien rawat inap di RSU Lubuk Linggau Sumatra Selatan. Jakarta. Program Studi KARS. FKM UI: Tidak dipublikasikan 